\title{
RESEARCH OF QUANTITATIVE AND QUALITATIVE CHARACTERISTICS OF GLUTEN OF WHEAT GRAINS DAMAGED BY THE WHEAT BUG
}

\begin{abstract}
Favorable weather and climate conditions for growing grain are also favorable for the livelihoods and reproduction of pests of grain stocks, and especially for wheat bug (Eurygaster integriceps Put.). Grain damaged by this pest loses its genetically incorporated properties, negative changes occur in the quantity and quality of gluten. Due to the ingestion of bug's saliva with its special enzymes into the grain, the baking properties of the flour from such grain deteriorate - the dough becomes liquid, sticky, it loses elasticity. Thus, the issue of further effective use of grain damaged by the shield bugis very urgent. This requires information on the dependence of the quantitative and qualitative characteristics of gluten on the content of grains damaged by the wheat bug.

The aim of the study was to establish patterns of change in the quantity and quality of gluten depending on the content of grains damaged by the wheat bug, which will increase the efficiency of the formation of batches for further use in the food industry. To achieve this goal, a number of tasks were solved: during the grain harvesting periods of 2015-2018, at the enterprises of the industry, wheat samples were taken with the content damaged by the wheat bug in the range of $0.5 \ldots 5.0 \%$, the quantity and quality were determined in them gluten, trends in the quantity and quality of gluten have been established depending on the content of damaged grains and their comparison with published data.

The object of the study was the gluten complex of wheat, with various contents of grains damaged by the wheat bug. The subject of research was the quantity and quality of gluten in samples of soft wheat of grades 2-3 of the 20152018 crop samples with various grains damaged by a wheat bug selected at enterprises in the Odessa region.

Based on the results of determining the quantity and quality of gluten in samples of the 2015-2018 crop and the available literature data on the quantity and quality of gluten in grain 2005-2007, a crop with the content of grain damaged by the wheat bug was shown to be $5.0 \%$, that between the amount of gluten and the content in the grain mass of the grains damaged by the wheat bug, there are no regularities.

Existing fluctuations in the amount of gluten are reliably associated with different origins of grain samples grown under different agrotechnological conditions, different protein contents, varietal characteristics of grain and other factors. The regularities of changes in the quality of gluten depending on the content of grain damaged by a wheat bug have been established - with an increase in the content of damaged grains, according to a linear law, the gluten quality index determined on the VDK device also increases. It was also established that the intensity of changes in the quality of gluten significantly depends on the content of grains damaged by the wheat bug; there was a slight increase in the quality index of gluten with the content of damaged grains up to $2.0 \%$, and its rapid growth with the content of damaged grains from $2.0 \%$ to 5,0\% It is shown that in the studied wheat samples with the content of grains damaged by the wheat bug up to 2.5..2.7\%, the VDK indicator belongs to the 2nd group of gluten quality - satisfactory weak and wheat belongs to 1-3 grades in this indicator. With a further increase in the content of grains damaged by the wheat bug, the index of VDK increases and gluten passes to the 3rd group - unsatisfactory weak, and the batch of wheat belongs to the 4th class.
\end{abstract}

Key words: wheat, grains are damaged by a wheat bug (Eurygaster integriceps Put.), the quantity and quality of gluten, ways to deal with a wheat bug (Eurygaster integriceps Put.).

\section{Problem statement}

Ukraine is a powerful agricultural country with incredibly great potential for growing various grains and oilseeds. In our country there are many factors for growing and harvesting rich crops: high-quality black soil, favorable climatic conditions, fundamental knowledge of agronomists in the field of sowing and cultivating the land, fields and crops.

Favorable weather and climatic conditions for growing grain, unfortunately, are also favorable for the livelihoods and reproduction of pests of grain stocks, and especially recently for harmful wheat bug (Eurygaster integriceps Put.). This insect causes great harm to farmers by a significant deterioration in the quality of wheat.

For farmers and enterprises, the issue of quantitative and qualitative wheat harvest is very important, because their profit depends on these indicators. In pursuit of high productivity, farmers purchase breeding varieties that are not genetically based on increased resistance to turtles.

In addition, not all sown areas and the adjacent territories are cultivated properly, populations of bugs migrate from untreated areas, and hit crops. In the spring, damage leads to the death of the central leaf and stem. Injections into the stem cause white bleached ear and underdevelopment of grain. Adult bugs and larvae also 
feed on grain. A dark spot forms at the injection sites, the grain becomes wrinkled, its similarity decreases. Due to the ingestion of its special enzymes into the grain along with the saliva of the bug, the baking properties of the flour deteriorate - the dough becomes liquid, sticky, loses its elasticity (floating bread) [1].

In many bakeries, when mixing dough, various improvers are used, during the interaction with which the effect of "harmful" enzymes from damaged grains is blocked. Such substances include dry gluten and its modification products, enzyme preparations, surfactants, various hydrocolloids, modified starches, organic acids, mineral salts, preservatives, acidifiers, numerous complex improvers developed recently, etc. [2].

For the first time, defective gluten in wheat, the grain of which was damaged by wheat bugs, was discovered in 1932 by the All-Union Grain Research Institute. Since then, a lot of research has been done on the diagnosis, nature and mechanism of grain damage and the impact of damage on the baking quality of flour, in particular gluten [3].

A harmful wheat bug lives on crops of grain crops only from two to three months, during which one generation of the population develops, the rest of the time they are in wintering places (windbreaks, forests). But during this short period of time, damaging mainly cereal grains, primarily wheat, the wheat bug can significantly reduce the yield, especially its quality. Quantitative crop losses are caused by bugs that overwintered [4].

Currently, a very important and relevant issue is the fact that the effect on the human body of an enzyme that gets into grains when bitten by a wheat bug has not yet been studied.

\section{Research of existing solutions to the problem}

Many methods have been developed to improve the quality of bread made from grain damaged by a wheat bug: increasing the acidity of the dough, increasing the amount of salt in the dough, improving the physical condition of gluten etc.

At flour milling and baking enterprises, there are certain methods that can improve the quality of flour with high values of the gluten quality index, which is measured in arbitrary units of the scale of the VDK device (gluten deformation meter). One of them is mixing batches of flour of different quality to obtain the final batch with specified quality indicators. In addition, there are currently a large number of substances that, when added to flour, improve its baking qualities, block the action of liquefy enzymes, the presence of which leads to a high value of the number of gluten deformation.

In addition, in the bakery the following changes are made to the technological process of dough making and baking in the bakery: the dough is prepared in an accelerated manner so that gluten during fermentation is less exposed to the negative effects of enzymes, reduce the proofing time, bread is baked at elevated temperature, and the dough is prepared using liquid yeast [5].

To obtain flour with high baking properties in flour mills according to the shortened scheme of the technological process, it is possible to improve its quality only by adding enzyme preparations of a different principle of action, primarily to adjust proteolytic and amylo lytic activity [6].

It should be noted that grains damaged by the wheat bug affect the vitreous nature of the batch. A mealy stain will appear on the vitreous grains, changing the color of the grain. On semi-vitreous and non-vitreous wheat, the definition of this indicator will be somewhat harder, because the color of the spot coincides with the color of the grain.

Currently, there are methods to combat the wheat bug, but without the comprehensive implementation of all methods it is impossible to achieve the highest possible quality indicators for wheat.

Currently, there are such measures to protect against wheat bugs:

1) The use of high quality seed with high resistance to insects;

2) Timely processing of fields and adjacent territories with insecticides;

3) Timely harvesting, because during early harvesting during threshing, larvae and young bugs die in which the chitinous layer has not yet hardened;

4) At the beginning of spring, winter crops are fed with potash and phosphorus fertilizers. After this, the sowing area should be qualitatively plowed [7];

5) Adjusted timing of the sowing campaign;

6) After harvesting, it is imperative to thresh and plow the land. The smell of grain fell into the ground, destroying the pest's feed base [7].

\section{The aim and objectives of the study}

The aim of the study was to establish patterns of change in the quantity and quality of gluten depending on the content of grains damaged by the wheat bug, which will increase the efficiency of the formation of batches for further use in the food industry.

To achieve this goal it is necessary to solve the following tasks

- during the grain harvesting periods of 20152018 , at the enterprises of the industry, select wheat samples with the content of those damaged by the bugbug in the range of $0.5 \ldots .5 .0 \%$;

- determine the quantity and quality of gluten in wheat samples with different contents of grains damaged by the wheat bug for a specified period;

- establish trends in quantitative and qualitative characteristics of gluten depending on the content of damaged grains and compare them with published data.

\section{Object and subject of research}

The object of the study was the gluten complex of wheat damaged by a wheat bug. The subject of research was the quantitative and qualitative characteristics of gluten taken from enterprises in the Odessa region of soft wheat samples of grades 2-3 of the 2015-2018 crop with a different content of grains damaged by a wheat bug.

\section{Methodology}

Wheat samples with different content of grains damaged by a wheat bug were taken during the harvesting period at the industrial enterprises of Odessa region. For research, annually in the period 2015-2018 years, 11 wheat samples were taken with the content of grains 
damaged by the wheat bug in the range $0 . .5 .0 \%$ in increments of $0.5 \%$.

Determination of the content of grains damaged by a wheat bug is carried out according to GOST 30483-97 Grain. Methods for determining the total and fractional content of weed and grain impurities; content of small grains and grain size; the content of wheat grains damaged by the bug; content of metal-magnetic impurities). To do this, from the sample weighing $10 \mathrm{~g}$, previously purified from grain and weedy impurities, grains damaged by the wheat bug, the mass of which from two parallel weights is expressed as a percentage with an accuracy of tenths, is selected according to the presence of specific characteristics.

Method for determining the amount of gluten (GOST 13586.1-68 Grain. Methods for determining the quantity and quality of gluten in wheat).

The grinded grain (meal) is thoroughly mixed and a weighed mass of $25 \mathrm{~g}$ or more is isolated, so as to ensure the release of crude gluten weighing at least 4 hours. The meal is placed in a porcelain mortar or cup and filled with water. The volume of water for kneading dough with a mass of a sample of $25 \mathrm{~g}$ is $14 \mathrm{~cm}^{3}$. After that, the dough is kneaded.

The formed dough in the ball is placed in a bowl and covered with glass (or a second cup) for 20 minutes. After that, gluten is washed under a weak stream of tap water over a thick silk or nylon sieve, kneading the dough lightly with your fingers. First, laundering is carried out carefully, not allowing pieces of dough to come off together with starch and shells, and more energetically after removing starch and shells. Randomly torn off gluten pieces are collected and attached to the total mass of gluten.

Having finished washing the gluten, it is squeezed between the palms, which are wiped dry with a towel from time to time. The pressed gluten is weighed, washed again for 2...3 minutes. Again squeeze and weigh. Gluten washing is considered complete for differences in weight between two weighings of not more than $0.1 \mathrm{~g}$. Crude gluten is expressed in mass fractions as a percentage of a portion of ground grain (meal).

For kneading dough, washing and determining the quality of gluten, ordinary tap water is used, the temperature of which must meet the requirements of $18 \pm 2{ }^{\circ} \mathrm{C}$.

Determining the quality of crude gluten (GOST 13586.1-68 Grain. Methods for determining the quantity and quality of gluten in wheat).

Gluten quality is understood as the totality of its physical properties: elongation, elasticity, viscosity, the ability to maintain physical properties over time.

The elastic properties of gluten were determined in arbitrary units of the VDK-7 device scale (gluten deformation meter).

A piece weighing $4 \mathrm{~g}$ is separated from the washed gluten (knead it 3-4 times with fingers), then form a ball and place it for 15 minutes in a bowl of water, the temperature of which must meet the requirements of $18 \pm 2{ }^{\circ} \mathrm{C}$. If gluten after washing is a spongy, friable mass and does not form a ball, then it is attributed to 2 groups without determining the quality of the device.
After 15 minutes of tracking in water, the gluten ball is placed in the center of the VDK-7 device table and the "Start" timer switch is pressed. The punch freely falls on gluten and compresses it. On the indicator display of the device shows a number characterizing the amount of elasticity of the studied gluten sample in arbitrary units of the scale.

\section{Results of the study.}

According to the purpose and objectives of the research, at the grain enterprises during the grain harvesting period from wheat 2015-2018 years, 11 samples were taken with the content of grain damaged by the bug in the range of $0 . .5 .0 \%$ in increments of $0 . .5 \%$ and it was determined quantity and quality of gluten there.

To compare and establish general trends in the quantity and quality of gluten from literary sources, information was taken on the quantitative and qualitative characteristics of grain damaged by a wheat bug in the period 2005-2007 years [8].

Based on the obtained research results and the available literature data on the quantitative and qualitative characteristics of gluten, depending on the content of grain damaged by the bug, the corresponding graphs were constructed and their analysis was carried out.

In Fig. 1 shows the results of studies on the effect of the content of grains damaged by a wheat bug on the amount of gluten. On the graphs, dashed lines show the changes in the amount of gluten in the grain of wheat from the $2005 . .2007$ years crop. It is seen that the largest gluten, almost independently of the content of grains damaged by the wheat bug, was in the 2005 wheat crop. In the 2006 grain crop, containing up to $3 \%$ of the grains damaged by the bug, there was less gluten. However, these graphs clearly show that there are no regularities between the amount of gluten and the content of grains damaged by the wheat bug in the grain mass. The existing fluctuations in the amount of gluten are in no way dependent on the content of grains damaged by the wheat bug and reliably associated with different origins of grain samples grown under different agro-technological conditions, different protein contents, varietal characteristics of grain and other factors.

In Fig. 2 it is shown with the characteristics of gluten quality (according the VDK adjustment - the characteristics of deformation and gluten) on behalf of the grains that damaged by wheat bug. On the graphs, as in Fig. 2, the dashed lines show the changes in the quality of gluten in the grain of wheat from the harvest of 20052007 years, and the solid ones in the grain of the harvest from 2015-2018 years.

The graphs clearly show a generalized trend towards an increase in the quality index of gluten with an increase in the content of grains damaged by a wheat bug.

In addition, two characteristic intervals with different growth rates of gluten quality index depending on the content of grains damaged by the wheat bug can be clearly distinguished from the graphs - the first interval is from 0 to $2.0 \%$, the second is from $2.0 \%$ to $5.0 \%$. At each of these intervals, a linear law of growth in the influence of the content of grains damaged by the wheat bug on the quality of gluten is seen, with the first of them 
showing an increase in the quality of gluten of VDK, while the second is growing rapidly.

Processing the data by the least squares method made it possible to describe the established changes in the quality of gluten depending on the proportion of grains damaged by the bug-bug with such linear equations:

$$
\begin{aligned}
& - \text { in the interval } 0 \ldots 2.0 \% \\
& \text { VDK }=80.51+1.31 x ; \\
& - \text { in the range of } 2.0 \ldots 5.0 \% \\
& \text { VDK }=55.40+14.02 x,
\end{aligned}
$$

where VDK is the quality of gluten, conv. units VDK device;

$x$ is the proportion of grains damaged by the wheat bug, $\%$.

The root-mean-square errors for the first and second intervals are $1.66 \%$ and $1.72 \%$, respectively, which indicates satisfactory convergence of the calculated and averaged over the years experimental and literature data. The linear dependencies of changes in the qual-

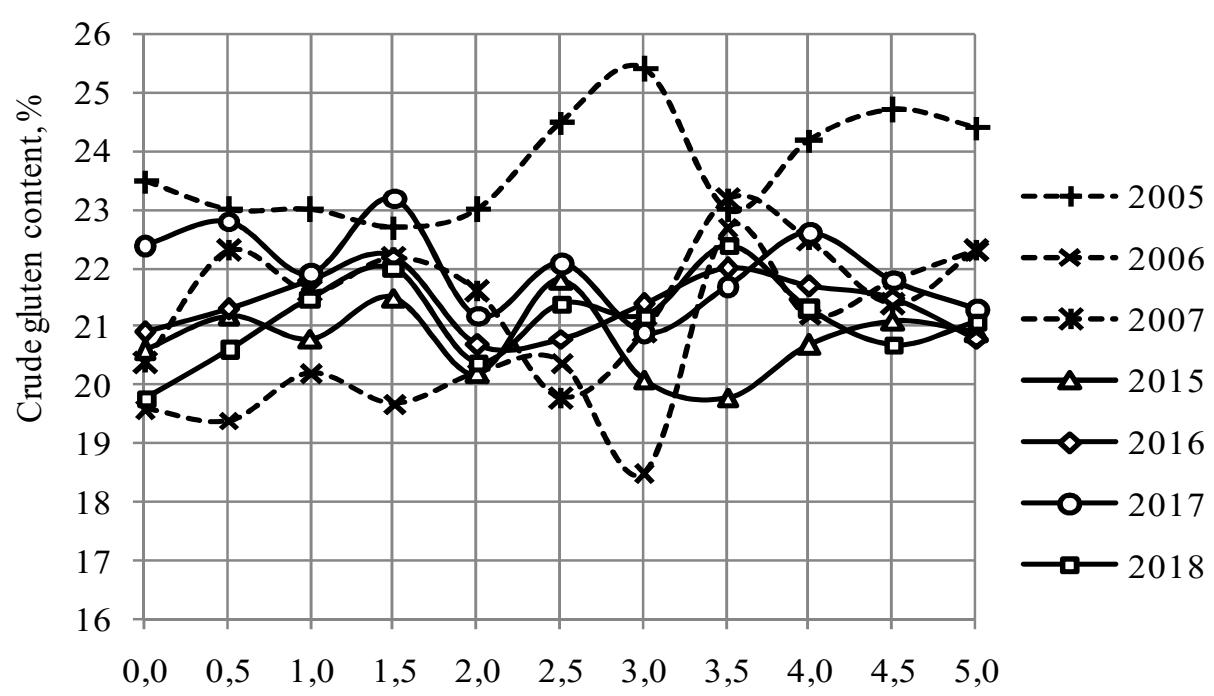

The content of grains damaged by the wheat bug, \%

Fig. 1 - Dependence of the amount of gluten on the content of wheat grains damaged by the wheat bug

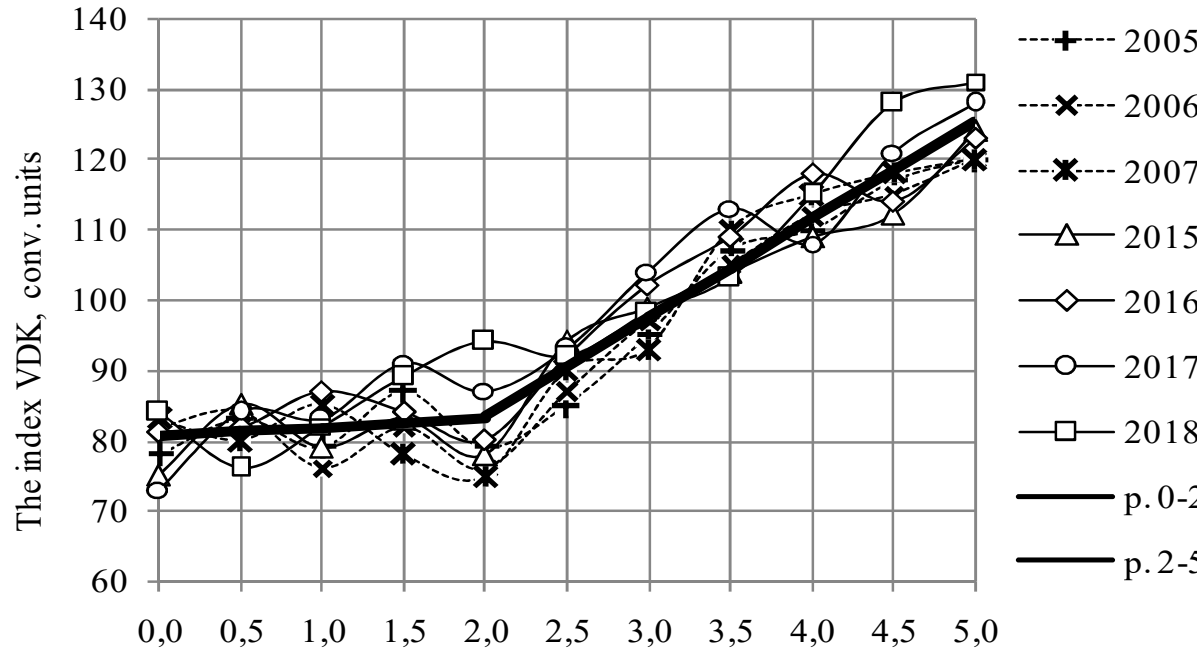

The content of gra ins damages by the wheat bug, $\%$

Fig. 2 - Dependence of the quality of gluten on the content of wheat grains damaged by the wheat bug ity of gluten are calculated according to the above equations; 2 thickened lines marked as "p. 0-2"and "p. 2-5" for the interval with the content of grains damaged by the wheat bug, $0 \ldots 2 \%$ and $2 \ldots 5 \%$, respectively. At a point with a damaged grain content of $2.0 \%$, the first and second equations give the same results -83 conv. units VDK device.

The obtained equations make it possible to predict changes in the gluten quality index when the content of grains damaged by the bug-bug is up to $5.0 \%$. When the content of damaged grains is up to $2.0 \%$, the rate of change of the quality indicator becomes 1.3 mind. Units for each percentage of damaged grains, and when the content of damaged grains in the range of $2.0 \ldots 5.0 \%$, it is significantly higher and amounts to 14.0 conv. units for each percentage of damaged grains.

Thus, the studies showed that it is possible to predict the quality of gluten with a different content of grains damaged by the wheat bug, which will more accurately predict the quality of consignments formed for various needs. This will contribute to a more rational use of wheat grain. In the future, there is a need for further research involving various varieties of wheat grown in different years in different agro-climatic zones. This will create an extensive database, investigate the effect of the wheat bug on the quality of gluten proteins and provide an opportunity to predict possible changes in gluten quality in advance. With an increase in the content of grains damaged by the bug bug, regardless of the class of wheat, the index of VDK increases.

\section{Conclusion}

1. Based on the results of determining the quantity and quality of gluten in samples of the 2015-2018 crop and the available literature data on the quantitative and qualitative characteristics of gluten in grain 2005-2007 years, the crop with the content of grain damaged by wheat bug up to $5.0 \%$ it was shown that:

between the amount of gluten and the content in the grain mass of the grains damaged by the wheat bug, there are no regularities. Existing fluctuations in the amount of gluten are reliably associated with different origins of grain samples grown under different agro- 
technological conditions and other factors;

- regularities of changes in the quality of gluten depending on the content of grains damaged by the wheat bug have been established - with an increase in the content of damaged grains according to the linear law, the gluten quality index determined on the VDK device also increases. It was also established that the intensity of changes in the quality of gluten significantly depends on the content of grains damaged by the wheat bug; there was a slight increase in the quality index of gluten with the content of damaged grains up to $2.0 \%$, and its rapid growth with the content of damaged grains from $2.0 \%$ to $5.0 \%$.

2. In the studied wheat samples with the content of grains damaged by the wheat bug up to $2.5 \ldots 2.7 \%$, the VDK indicator belongs to the 2nd group of gluten quality - satisfactory weak, according to this indicator, the wheat belongs to grades 1-3. With a further increase in the content of grains damaged by the wheat bug, the index of VDK increases and gluten passes to the 3rd group - unsatisfactory weak, and, accordingly, the batch of wheat belongs to the 4 th class.

\section{REFERENCES}

1. Klop shkidliva cherepashka (klop vrednaya cherepashka) URL: https://superagronom.com/shkidnikinapivtverdokrili-hemiptera/shkidliva-cherepashka-id16658 (data zvernennya 17.03.2019).

2. Polipshuvachi boroshna ta hliba. URL: https://chemiday.com/uk/encyclopedia/14-1-0-148 (data zvernennya 31.03.2019).

3. Pshenicya. Shkidnik nomer odin pshenichnogo polya - klop shkidliva cherepashka. URL: http://agroua.net/plant/catalog/cg-1/c-1/info/cag-319/ (data zvernennya 22.03.2019)

4. Klop shkidliva cherepashka ta problema yakosti zerna ozimoyi pshenici. https://propozitsiya.com/ua/klop-shkidliva-cherepashka-ta-problema-yakosti-zerna-ozimoyi-pshenici zvernennya 17.03.2019)

5. Poshkodzhene i nepovnocinne zerno ta jogo vikoristannya. URL: https://propozitsiya.com/ua/poshkodzhene-inepovnocinne-zerno-ta-yogo-vikoristannya (data zvernennya 22.03.2019).

6. Zhigunov D.O. Koval ova V.P. Pidvishhennya khlibopekarskoyi yakosti pshenichnogo boroshna. // Progresivni tekhnika ta tekhnologiyi kharchovikh virobnicztv restorannogo gospodarstva i` torgivli: zb. nauk. pr./vidpov. red. O.I. Cherevko.-Kharkiv: KhDUKhT, 2018. - Vip. 1(27). - S. 280-291.

7. Klop «vrednaya cherepashka» - opasnyj vrag zlakovyh kultur. URL: https://agrostory.com/infocentre/knowledge-lab/bug-bad-bug-a-dangerous-enemy-of-cereal-crops (data zvernennya 17.03.2019)

8. Shkidnik klop-cherepashka. URL: http://www.nibulon.com/r/files/1082;1083;1086;1087;_1095;1077;1088; 1077;1087;1072;1096;1082;1072;.pdf (data zvernennya 01.04.2019).

Г.М. Станкевич, д-р техн. наук, професор, E-mail: georgii.stn@gmail.com А.В. Борта, канд. техн. наук, доцент, E-mail: borta.alla@ukr.net

А.А. Пенаки, аспірант Кафедра технології зберігання зерна Одеська наџіональна академія харчових технологій, вул. Канатна, 112, Одеса, 65039, Украӥна

\section{ДОСЛІДЖЕННЯ КІЛЬКІСНО-ЯКІСНИХ ХАРАКТРИСТИК КЛЕЙКОВИНИ ЗЕРНА ПШЕНИЦІ, ПОШКОДЖЕНОГО КЛОПОМ-ЧЕРЕПАШКОЮ}

\section{Анотація}

Сприятливі погодно-кліматичні умови для вирощування зерна є також є сприятливими для життєдіяльності та розмноження шкідників хлібних запасів, $i$, особливо, для клопа-черепашки. Зерно, пошкоджене циим шкідником, втрачає свої генетично закладені властивості, відбуваються негативні зміни у кількості та якості клейковини. Внаслідок потрапляння у зерно разом зі слиною клопа-черепашки його особливих ферментів погіршуються хлібопекарські властивості борошна з такого зерна - тісто стає рідким, липким, втрачає пружність. Таким чином, дуже актуальним постає питання подальшого ефективного використання зерна, пошкодженого клопом-черепашкою. Для цьього необхідна інформація про залежність кількісно-якісних характеристик клейковини від вмісту пошкодженого клопом-черепашкою зерен.

Метою дослідження було встановлення закономірностей зміни кількості та якості клейковини в залежності від вмісту пошкоджених клопом-черепашкою зерен, щуо дозволить підвищити ефективність формування партій для подальшого використання у продовольчій промисловості. Для досягнення поставленої мети було вирішено ряд завдань: у зернозаготівельні періоди 2015...2018 років на підприємствах галузі були відібрані зразки пшениці з вмістом пошкоджених клопом-черепашкою у діапазоні 0,5..5,0%, визначено у них кількість $i$ якість клейковини, встановлено тенденції зміни кількості і якості клейковини залежно від вмісту пошкоджених зерен та порівняно їх з літературними даними.

Об'єктом дослідження був клейковинний комплекс пшениці, пошкодженої клопом-черепашкою. Предметом досліджень були кількісно-якісні характеристики клейковини відібраних на підприємства Одеської об- 
ласті зразків м'якої пшениці 2-3 класів 2015-2018 років врожаїв з різним вмістом зерен, пошкоджених клопомчерепашкою.

На основі результатів визначення кількості та якості клейковини у зразках 2015 ...2018 років урожаю та наявних літературних даних з кількісно-якісних характеристик клейковини у зерні $2005 . .2007$ років урожаю з вмістом пошкодженого клопом-черепашкою зерна до 5,0 \% було показано, що між кількістю клейковини та вмістом в зерновій масі пошкоджених клопом-черепашкою зерен, відсутні будь-які закономірності. Наявні коливання кількості клейковини вірогідно пов'язані з різним походженням зразків зерна, вирощених у різних агротехнологічних умовах та інших чинників. Встановлено закономірності зміни якості клейковини в залежності від вмісту пошкодженого клопом-черепашкою зерна - зі збільшенням вмісту пошкоджених зерен за лінійним законом збільшується і показник якості клейковини, визначений на приладі ВДК. Встановлено також, що інтенсивність зміни якості клейковини суттєво залежить від вмісту пошкоджених клопом-черепашкою зерен - відмічено незначне зростання показника якості клейковини при вмісті пошкоджених зерен до 2,0%, та стрімке його зростання при вмісті пошкоджених зерен від 2,0\% до 5,0 \%. Показано, що у досліджених зразках пшениці з вмістом пошкоджених клопом-черепашкою зерен до 2,5 ...2,7 \% показник ВДК відноситься до 2 групи якості клейковини - задовільної слабкої $і$ за иим показником пшениия відноситься до 1-3 класів. При подальшому збільшенні вмісту пошкоджених клопом-черепашкою зерен, показник ВДК збільшується $і$ клейковина переходить до 3-ї групи - незадовільної слабкої, а партія пшениці відноситься до 4 класу.

Ключові слова:пшениця,зерна пошкоджені клопом-черепашкою, кількість та якість клейковини, иляхи боротьби з клопом-черепашкою.

1. Клоп шкідлива черепашка (клоп вредная черепашка). URL:https://superagronom.com/shkidnikinapivtverdokrili-hemiptera/shkidliva-cherepashka-id16658 (дата звернення 17.03.2019).

2. Поліпшувачі борошна та хліба. URL: https://chemiday.com/uk/encyclopedia/14-1-0-148 (дата звернення 31.03.2019).

3. Пшениця. Шкідник номер один пшеничного поля - клоп шкідлива черепашка. URL: http://agroua.net/plant/catalog/cg-1/c-1/info/cag-319/ (дата звернення 22.03.2019).

4. Клоп шкідива черепашка та проблема якості зерна озимої пшениці. URL: https://propozitsiya.com/ua/klop-shkidliva-cherepashka-ta-problema-yakosti-zerna-ozimoyi-pshenici (dama звернення 17.03.2019).

5. Пошкоджене $i$ неповноцінне зерно та його використання. URL: https://propozitsiya.com/ual poshkodzhene-i-nероvnocinne-zerno-ta-yogo-vikoristannya (дата звернення 22.03.2019).

6. Жигунов Д.О., Ковальова В.П. Підвищення хлібопекарської якості пшеничного борошна. // Прогресивні техніка та технології харчових виробництв ресторанного господарства і торгівлі: зб. наук. пр./ відпов. ред. О.І. Черевко.-Харків: ХДУХТ, 2018. - Вип. 1(27). - C. 280-291.

7. Клоп «вредная черепашка» - опасный враг злаковых культур. URL: https://agrostory.com/infocentre/knowledge-lab/bug-bad-bug-a-dangerous-enemy-of-cereal-crops (дата звернення 17.03.2019).

8. Шкідник клоп-черепашка. URL: http://www.nibulon.com/r/files/1082;1083;1086;1087; 1095;1077; 1088;1077;1087;1072;1096;1082;1072;.pdf (дата звернення 01.04.2019).

Received 04.04.2019.

Reviewed 06.05.2019
Revised 02.06.2019

Approved 03.09.2019.

\section{Cite as Vancouver Citation Style}

Stankevych G., Borta A., Penaki A. Research of quantitative and qualitative characteristics of gluten of wheat grains damaged by the wheat bug. Grain Products and Mixed Fodder's, 2019; 19 (3): 7-12. DOI: https://doi.org/

\section{Cite as State Standard of Ukraine 8302:2015}

Research of quantitative and qualitative characteristics of gluten of wheat grains damaged by the wheat bug / Stankevych G. et al. // Grain Products and Mixed Fodder's. 2019. Vol. 19, Issue 3. P. 7-12. DOI: https://doi.org/ 